\title{
Sulfur-enhanced reductive bioprocessing of cobalt-bearing materials for base metals recovery
}

Araujo Santos, Ana Laura; Dybowska, Agnieszka; Schofield, Paul; Herrington, Richard; Johnson, Barrie

\section{Hydrometallurgy}

DOI:

10.1016/j.hydromet.2020.105396

Published: 01/08/2020

Peer reviewed version

Cyswllt i'r cyhoeddiad / Link to publication

Dyfyniad o'r fersiwn a gyhoeddwyd / Citation for published version (APA):

Araujo Santos, A. L., Dybowska, A., Schofield, P., Herrington, R., \& Johnson, B. (2020). Sulfurenhanced reductive bioprocessing of cobalt-bearing materials for base metals recovery. Hydrometallurgy, 195, [105396]. https://doi.org/10.1016/j.hydromet.2020.105396

\footnotetext{
Hawliau Cyffredinol / General rights

Copyright and moral rights for the publications made accessible in the public portal are retained by the authors and/or other copyright owners and it is a condition of accessing publications that users recognise and abide by the legal requirements associated with these rights.

- Users may download and print one copy of any publication from the public portal for the purpose of private study or research.

- You may not further distribute the material or use it for any profit-making activity or commercial gain

- You may freely distribute the URL identifying the publication in the public portal ?
}

Take down policy

If you believe that this document breaches copyright please contact us providing details, and we will remove access to the work immediately and investigate your claim. 
Ana Laura Santos ${ }^{1 *}$, Agnieszka Dybowska², Paul F. Schofield²,

Richard J. Herrington² and D. Barrie Johnson ${ }^{1}$

6

7 1School of Natural Sciences, Bangor University, Bangor, LL57 2UW, UK

$8 \quad$ 2Department of Earth Sciences, Natural History Museum, London, SW7 5BD, UK

9

*Corresponding author; ana.santos@bangor.ac.uk; Tel. +4401248 382832

11

12

Keywords: acidophilic bacteria, cobalt, limonitic laterite, nickel, ore processing residues,

reductive bioleaching

14

15 


\section{Abstract}

17

The abundance of limonitic laterite ores in tropical and sub-tropical areas represents a large, and mostly unexploited, cobalt resource. Bioprocessing oxidised ores, and also waste materials such as tailings and processing residues, using acidophilic microorganisms to catalyse the reductive dissolution of iron and manganese minerals, is an environmentally benign alternative approach of extracting valuable base metals associated with these deposits. This work describes results from laboratory-scale experiments in which five cobaltbearing materials, three primary limonitic laterite ores and two processing residues (filter dust and slag), all sourced from mines and a processing plant in Greece, were bioleached under reducing conditions by a consortium of acidophilic bacteria (using elemental sulfur as electron donor) in stirred tank bioreactors at $\mathrm{pH} 1.5$ and $35^{\circ} \mathrm{C}$. Whilst the target metal, cobalt, was successfully bioleached from all five materials (40 - 50\% within 30 days) the extraction of some other metals was more variable (e.g. between 2 and $48 \%$ of iron). Concentrations of soluble cobalt were highly correlated, in most cases, with those of manganese, correlating with the finding that cobalt was primarily deported in manganese (IV) minerals. Acid consumption also differed greatly between mineral samples, ranging between 3 and 67 moles $\mathrm{H}_{2} \mathrm{SO}_{4} \mathrm{~g}^{-1}$ cobalt extracted. Comprehensive mineralogical analysis of the three limonitic samples before and after bioprocessing revealed significant variations between the ores, and demonstrated that elemental and mineralogical variabilities can greatly impact their amenability for reductive bioleaching. 


\section{Introduction}

The global demand for cobalt has greatly accelerated over the past 30 years, reflecting its increased use as an essential constituent of high technology materials, such as rechargeable batteries, superalloys and catalysts. Cobalt occurs in similar abundance to many other base metals such as copper and zinc in the earth's crust, though rarely in concentrations and amounts that have made it economically viable to be mined as a primary resource (Roberts and Gunn, 2014). In 2011, the European Union identified cobalt as a critical raw material, being fundamental to industry and essential for enabling technological development, and requiring reliable and sustainable supply. The Democratic Republic of Congo is the world's leading source of mined cobalt, accounting for approximately $70 \%$ of global cobalt production, and China is the world's leading consumer, with over $80 \%$ being used to produce rechargeable batteries (US Geological Survey, 2020). With the exception of the Bou Azzer cobalt mine in Morocco, cobalt is obtained as a secondary product of copper and nickel (from sulfide ores) and nickel (from lateritic ores) production (Roberts and Gunn, 2014).

Laterites are iron-rich deposits mostly found in tropical and subtropical areas. They are formed during the pervasive weathering of surface-located ultramafic rock leading to oxidation and precipitation of iron and enrichment of residual elements such as nickel and cobalt. The limonite layer of a laterite deposit typically contains $40-60 \%$ goethite $(\mathrm{FeO} \cdot \mathrm{OH})$ along with $0.8-1.5 \%$ nickel and $0.05-0.2 \%$ cobalt (Dalvi et al., 2004). Nickel in limonite is typically associated with iron (III) minerals whereas cobalt is associated with manganese (IV) minerals, such as asbolane $\left((\mathrm{Ni}, \mathrm{Co})_{x} \mathrm{Mn}(\mathrm{O}, \mathrm{OH})_{4} \cdot \mathrm{nH}_{2} \mathrm{O}\right)$ (Lambiv Dzemua et al., 2013). Although, $60 \%$ of the world's nickel production currently derives from sulfide ores, lateritic ores account for $70 \%$ of global nickel reserves (Dalvi et al., 2004).

Current technologies used for processing laterites include pyrometallurgical (e.g. ferronickel and matte smelting) and hydrometallurgical (e.g. high-pressure acid leaching) methods, and the hybrid Caron process, all of which require high energy and/or chemical consumption (McDonald et al., 2008). Heap leaching technologies are proposed as low energy 
alternatives with less specificity on the mineralogy of the laterite but a longer duration period prior to steady state production (Oxley et al., 2016). Cobalt is generally present in one or two orders of magnitude less than nickel in laterites, and therefore not usually considered an economically viable source of this metal. Cobalt can also be found in waste materials generated by processing laterites, including tailings (Marrero et al., 2015) and processing residues (e.g. slags) where concentrations may be greater than in the primary ores.

Several studies have demonstrated that limonite ores and laterite tailings are amenable to bioprocessing by acidophilic bacteria at relatively low temperatures (Hallberg et al., 2011; Johnson and du Plessis, 2015; Marrero et al., 2015; Smith et al., 2017). The approach used has been described as 'biomining in reverse gear' and is mediated by many of the same acidophilic microorganisms that are also used in conventional biomining operations, but in set-ups engineered to facilitate iron reduction rather (as in conventional biomining) iron oxidation. When processing oxidised ores, such as laterites, it is necessary to add an extraneous source of energy for the bacteria in order to provide an electron donor that can be coupled to iron reduction. Both organic and inorganic electron donors can be used, though zero-valent sulfur (ZVS) has been the material of choice, both because of its low cost and the fact that its oxidation, coupled to oxygen or soluble iron (III), generates sulfuric acid which helps to maintain the acidic conditions that enhance both metal dissolution and the activities of the acidophilic microorganisms.

Lateritic ores have the potential to become major sources of cobalt in the future, and developing more environmentally benign technologies for processing these materials is an urgent issue. This work, carried out as part of the EU-funded CROCODILE project (https://h2020-crocodile.eu/), describes results from bioprocessing different oxidised cobaltbearing materials, including three primary limonitic laterite ores from different mines in Greece, and two processing residues. The materials were all bioleached by a consortium of acidophilic bacteria in stirred tank bioreactors. 


\section{Material and methods}

\subsection{Sample characterisation}

.

Five cobalt-bearing materials were bioprocessed at low $\mathrm{pH}$ and mesophilic temperatures (Table 1). All samples were provided by LARCO (General Mining and Metallurgical Company SA, Larymna, Greece), a partner in the EU-funded CROCODILE project. Three of these materials were limonitic ores from different mining operations in northern and central Greece, and the other two, a slag and a black filter dust, were wastes generated at a smelting plant for ferronickel production. Sample L1 was a very fine-grained black dust and L2 a crushed, black porous slag with occasional small $(<500 \mu \mathrm{m})$ metallic beads. The Kastoria (sample L3) limonite zone forms the upper part of an in situ laterite deposit, whilst at Agios loannis (sample L4) and Evia (sample L5), the deposits are reworked karstic types, dominated by oxides with the Agios loannis limonite developed below a bauxitic laterite (Herrington et al., 2016). The three limonite samples were ground using a disc mill with a $500 \mu \mathrm{m}$ disc separation, homogenised and sieved to $<900 \mu \mathrm{m}$. Mineralogical and chemical analyses of samples and bioleached residues were carried out using a combination of techniques, including induction coupled plasma atomic emission spectroscopy (ICP-AES), induction coupled plasma mass spectrometry (ICP-MS), X-ray powder diffraction (XRD; PANalytical X'Pert Pro a1 scanning diffractometer) and thermogravimetry/differential thermal analysis (TG-DTA; TA Instruments SDT Q600). Detailed characterisation of cobalt hosting mineral phases was performed using scanning electron microscopy (SEM; Zeiss EVO 15LS SEM) and electron probe micro analyser (EPMA; Cameca SX100).

\subsection{Bacterial cultures}

A mixed culture consortium of acidophilic iron-oxidizing/reducing and sulfur-oxidizing bacteria were used in experimental work. The consortium contained Acidithiobacillus (At.) ferrooxidans ${ }^{\top}$ and At. ferrooxidans strain CF3, At. ferriphilus ${ }^{\top}$, At. ferridurans $^{\top}$, Sulfobacillus 

maintained at Bangor University. A starter culture of the consortium was set up in shake flask containing $100 \mathrm{~mL}$ of liquid medium, containing basal salts and trace elements (Ñancucheo et al., 2016), $100 \mu \mathrm{M}$ ferrous sulfate and $5 \%(\mathrm{w} / \mathrm{v}) \mathrm{ZVS}$ at $\mathrm{pH} 2.5$, and incubated at $35^{\circ} \mathrm{C}$ in an orbital shaker.

\subsection{Reductive bioleaching experimental set up}

Bioreactor vessels ( $2 \mathrm{~L}$ working volume) coupled to FerMac 300 modular units that controlled $\mathrm{pH}$, temperature and agitation (Electrolab, UK) were commissioned for each experiment, each using one of the five cobalt-bearing materials. Liquid medium containing basal salts and trace elements was added to each reactor vessel, followed by $1 \%(\mathrm{w} / \mathrm{v})$ ZVS. All reactors were heat-sterilised at $110^{\circ} \mathrm{C}$ for 60 min and ferrous sulfate $(100 \mu \mathrm{M})$ and $100 \mathrm{~mL}$ of the starter culture were added to the reactor, when cool. The $\mathrm{pH}$ in the bioreactors was maintained at 1.5 by automated addition of $1 \mathrm{M} \mathrm{H}_{2} \mathrm{SO}_{4}$ or $1 \mathrm{M} \mathrm{NaOH}$ and temperature fixed at $35^{\circ} \mathrm{C}$. All reactors were stirred at $150 \mathrm{rpm}$. The bioreactors were initially aerated with sterile atmospheric air in order to promote biomass growth using ZVS as the electron donor coupled to the reduction of molecular oxygen. Seven to ten days after the bioreactor inoculation, the gas supply was switched to oxygen-free nitrogen (OFN) to generate anaerobic conditions. Each cobalt-bearing material was added to the bioreactors at $5 \%(\mathrm{w} / \mathrm{v})$ solid load. Volumes of acid or alkali consumed in order to maintain the $\mathrm{pH}$ of the bioreactor at 1.5 were recorded and cumulated daily. Liquid samples were withdrawn at regular intervals, $\mathrm{pH}$ and redox potential measured off-line, and metals concentration determined. Reductive bioleaching of the five samples was carried out for 25 - 30 days. At the end of each experiment, the solid phase was separated from the liquid phase (pregnant leaching solution; PLS) by filtration through Whatman (UK) \#1 filter papers. The PLS was stored at $4-10^{\circ} \mathrm{C}$, and solid residues dried at room temperature, ground to fine powders using a pestle and mortar, and analysed for their mineralogical and geochemical compositions. 
Concentrations of soluble iron (II) were determined using the Ferrozine assay (Stookey, 1970). To measure concentrations of total soluble iron, an excess of ascorbic acid was used in order to reduce soluble iron (III) to iron (II) and the resulting solutions analysed again using the Ferrozine reagent. Concentrations of transition metals in leachates were measured using a SpectrAA Duo atomic absorption spectrophotometer (Varian, UK). $\mathrm{pH}$ electrodes were coupled to an Accumet $50 \mathrm{pH}$ meter.

\subsection{Biomolecular analysis} acidophilic microorganisms maintained at Bangor University.

\subsection{Characterisation of the cobalt-bearing materials}


Mineralogical analysis showed that the filter dust (L1) was dominated by quartz and a spinel (magnetite), and also contained silicates, phyllosilicates and clay minerals, while calcite $\left(\mathrm{CaCO}_{3}\right)$ was identified as a minor phase. The processed slag (L2) was essentially an amorphous glassy phase with traces of maghemite and olivine (Table 2).

Quartz occurred as a major mineral phase in all three limonite ore samples. Goethite, serpentine and calcite were also identified as major phases in sample $\mathrm{L} 3$, which additionally contained hematite and low amounts of phyllosilicate and clay minerals. In sample L4 both goethite and hematite were abundant phases, and phyllosilicates including clay minerals were found in trace amounts. In sample L5, hydrated hematite was identified as the main iron (III) oxide phase rather than goethite. Chlorite, smectite and serpentine were also present and, unlike the other laterites, it also contained two carbonate minerals, calcite and ankerite $\left(\mathrm{Ca}(\mathrm{Fe}, \mathrm{Mg}, \mathrm{Mn})\left(\mathrm{CO}_{3}\right)_{2}\right)$ the latter in low abundance.

The chemical composition of the samples is shown in Table 3. The processing residues (samples L1 and L2) consisted predominantly of silicon and iron. The slag (L2) had more iron than the dust (L1) but contained an order of magnitude less nickel. Laterite samples L3, L4 and L5 had similar concentrations of silicon to each other. Sample L4 contained $\sim 350 \mathrm{~g} \mathrm{~kg}^{-1}$ iron which was almost twice as much as L3. Sample L4 contained very low levels of calcium compared to L3 and L5, but concentrations of aluminium, vanadium and chromium were greater. Sample L3 differed from both L4 and L5 in containing $\sim 3$ to 4-times more magnesium, having a very low aluminium content and the lowest concentration of chromium of all three laterites. Concentrations of nickel were similar in L3 and L4, but were much smaller ( $50 \%$ less) in L5. The filter dust (L1) had the highest concentration of cobalt, and the slag (L2) the lowest, of the five samples tested.

In the filter dust (L1) and all laterite samples (L3, L4 and L5) cobalt was associated mainly with manganese within lithiophorite-asbolane intermediate Mn-oxyhydroxides. This mineral was found to contain between 0.79 and $9.47 \mathrm{wt} \%$ of Co (average value Co $3.21 \mathrm{wt} \%$ ). Cobalt was also present in goethite in samples $L 3$ and $L 4(0.03$ to $0.27 \mathrm{wt} \%$, average value $0.04 \mathrm{wt} \%$ ), in the smectite of L5 (most likely nontronite 0.03 to $0.13 \mathrm{wt} \%$, average value 0.08 
$\mathrm{wt} \%$ ), in manganese carbonate ( $\mathrm{L} 3$ only; 0.03 to $0.27 \mathrm{wt} \%$, average value $0.15 \mathrm{wt} \%$ ) and in chromites (0.03 wt $\%$ to $0.15 \mathrm{wt} \%$, average value $0.06 \mathrm{wt} \%)$. Manganese carbonate and chromite were present in these samples in very low abundances, below the detection limit of XRD, but were observed in SEM and EPMA.

\subsection{Sulfur-enhanced reductive bioleaching}

The consortium of acidophilic iron-oxidising bacteria used in bioreactor experiments, was able to couple the oxidation of ZVS to the reduction of iron (III) under anaerobic conditions. The reductive dissolution of iron (III) (hydroxy)-oxide minerals was accompanied by increasing concentrations of soluble (ferrous) iron and other metals (Fig. 1).

Cobalt was effectively leached from all five Co-bearing materials. A rapid increase in cobalt dissolution occurred in the first 48 hours, followed by a slower phase of continuous dissolution (Fig. 1a). The kinetic data suggest that more protracted leaching would have enabled greater extraction of both cobalt and nickel for most of the samples tested (Figs. 1a and $1 \mathrm{~b})$. Manganese solubilisation followed a similar trend to that of cobalt, with the exception of the filter dust sample L1 (Fig. 1c). Concentrations of soluble manganese were highly correlated with those of cobalt, with regression coefficients $>0.90$, again with the exception of sample L1 where the value was 0.86 . Data of nickel and iron extraction from the Co-bearing materials are shown in Fig $1 \mathrm{~b}$ and 1d, respectively. Concentrations of nickel in the PLS ranged from $150 \mathrm{mg} \mathrm{L}^{-1}$ for $\mathrm{L} 4$ to $390 \mathrm{mg} \mathrm{L}^{-1}$ for L2. Iron solubilisation also varied greatly, with the smallest concentration of $400 \mathrm{mg} \mathrm{L}^{-1}$ total soluble iron for $L 4$ and the largest $\left(9,400 \mathrm{mg} \mathrm{L}^{-1}\right)$ for the slag (L2). There was a strong correlation between iron and nickel solubilised $\left(R^{2}>0.90\right)$ for all laterite ores, but the values were lower $(\sim 0.80)$ for both processing residues.

By inducing anaerobic conditions, a major change in solution chemistry occurred, from one dominated by iron (III) to one dominated by iron (II), though this was more protracted with limonite sample L4. In most cases, over $80 \%$ of total soluble iron was present as iron (II) in less than 24 hours after gassing with OFN, though with sample L4 this figure was not reached 
until day 20 (Fig. 2a). These changes were also reflected in redox potentials, as shown in Fig 2b. For limonite samples $L 3$ and $L 5, E_{h}$ values sharply decreased (by $\sim+100 \mathrm{mV}$ ) in the first 24 hours, stabilising at between +620 and $+640 \mathrm{mV}$, but for sample $L 4$, the fall in $E_{h}$ was much slower, taking about 20 days to stabilise at $\sim+620 \mathrm{mV}$. Redox potentials of PLS of both processing residues decreased to below $+600 \mathrm{mV}$ by day 2 and stabilised at $+550 \mathrm{mV}$ for $\mathrm{L} 1$ and $\sim+400 \mathrm{mV}$ for $\mathrm{L} 2$.

The reductive dissolution of iron (III) (hydroxy)oxides (shown for goethite in Eq. 1) is a proton-consuming reaction and addition of sulfuric acid was necessary to maintain solution $\mathrm{pH}$ at 1.5 .

$$
6 \mathrm{FeO} \cdot \mathrm{OH}+2 \mathrm{~S}^{0}+10 \mathrm{H}^{+} \rightarrow 6 \mathrm{Fe}^{2+}+\mathrm{SO}_{4}^{2-}+8 \mathrm{H}_{2} \mathrm{O}
$$

Cumulative acid consumption throughout each of the experiments is shown in Fig. 3. Sample L4 consumed far less acid (60 mmoles) than the other samples, which corresponded to this material containing only trace amounts of carbonate minerals and showing lower rates of iron dissolution. Samples L1, L3 and L5 consumed over 380 mmoles sulfuric acid to maintain pH at 1.5 , while the slag waste (L2) consumed 730 mmoles.

Extraction of cobalt was similar with all five samples, with about $40-50 \%$ solubilised over the timescale of the experiments (Table 4). Dissolution of nickel varied greatly, with recoveries varying between $37 \%$ for $L 4$ and $73 \%$ for $L 3$. The extent of iron solubilisation from all of the limonite ores was less than that of both cobalt and nickel (and was only $2 \%$ for sample L4) but was considerably higher for both of the processing residues (Table 4).

In general, analysis of the solid phase bioleaching residues supported results obtained with the PLS, with the major discrepancies most likely due to the potential for heterogeneity and the very small sample volume analysed in the solid residue (Supplementary Table S1). $\mathrm{XRD}$ analysis showed that there had been some dissolution of ferric iron minerals, and residual ZVS was also detected in all residues (Fig. 4). In addition, gypsum precipitated in all samples except for L4, which had the lowest Ca content and did not contain detectable carbonates. Analysis of the bioleached filter dust (L1) residue revealed that there had been a 
loss of magnetite, carbonate and a lower clay mineral content due to bioleaching. Carbonate

262 (in L3 and L5) and serpentine were removed during low $\mathrm{pH}$ bioleaching of all the laterite

263 samples and there were also lower clay contents in the bioleached residues. The removal of serpentine was most prominent in sample L3, where this phase was much more abundant than in samples L4 and L5. For the limonite samples, the strong correlation between cobalt and manganese suggested that cobalt was solubilised, predominantly, from manganese oxyhydroxide minerals. This was also confirmed by SEM investigation of the bioleaching residues, where it was observed that manganese-rich phases were no longer detected or were in a much lower abundance in the leached residues (Supplementary Fig. S1).

Bacterial diversities in the final PLS were much lower than that in the initial inocula. At. ferrooxidans and Sb. thermosulfidooxidans were detected in L3 leachate, while only At. ferrooxidans was detected at the end of bioleaching of L4 and L5 limonites. All attempts to amplify $16 \mathrm{~S}$ rRNA genes from both L1 and L2 leachates were unsuccessful.

\section{Discussion}

The abundance of limonitic laterite ores in tropical and sub-tropical areas represent a large resource of cobalt yet to be exploited. Previous studies have shown that different primary target metals, including nickel (Johnson et al., 2013), copper (Ñancucheo et al., 2014) and cobalt (Smith et al., 2017) can be recovered from limonitic ores via reductive bioleaching. There have, however, been no previous reports of bioprocessing lateritic ores located in Europe, or none about using this approach to recover metals from ore processing wastes, with the exception of laterite tailings from the CARON process (Marrero et al., 2015). In addition, the comprehensive inventory of the detailed mineralogy of the three limonitic samples used in the present study illustrate how variations between lateritic ores, even within the same geographical location, can impact their amenability for bioleaching.

The smelting operation at Larymna (Greece) generates different solid waste materials, one being a fine dust which is collected in filters during the process of ferronickel production, 
which contained greater concentrations of cobalt and nickel than in the limonite ores tested (Table 3). Smelting of ore in an electric furnace at the Larymna site produces a metallic phase, which contains most of the nickel, and a slag phase, which accounts for $85 \%$ of the furnace feed. These are separated; the former is further processed, and the latter is mostly discarded. In contrast to the filter dust, the slag contained less cobalt and nickel than the limonitic ores tested. The three limonites, sourced from different mines in Greece, showed significant variability in elemental and mineralogical composition.

Iron (III) minerals are known to be highly variable in terms of their susceptibility for reductive dissolution at low $\mathrm{pH}$ (Bridge and Johnson, 2000). The mechanism by which acidophilic prokaryotes accelerate the dissolution of iron (III) minerals is thought to be by reducing small amounts of soluble iron (III) produced by the acid dissolution of these minerals, shifting the equilibrium between iron (III) present in the solid and soluble phases (Johnson and du Plessis, 2015). The rate-limiting step is usually the abiotic acid dissolution of the mineral with, for example, goethite being much more susceptible than hematite. Acidophilic bacteria that couple the oxidation of ZVS to the reduction of iron (III) can, however, also oxidise iron (II) when oxygen is present, so anaerobic conditions are usually required for reductive mineral bioprocessing to occur. The reduction of iron (III) has also been observed in aerobic cultures of acidophiles, such as Acidithiobacillus caldus and Acidithiobacillus thiooxidans, that do not oxidise iron (Johnson et al., 2017), but the mechanism by which this happens is unknown, and these bacteria do not grow via iron respiration. The reductive dissolution of iron (III) and manganese (IV) oxyhydroxide minerals, such as goethite and lithiophorite-asbolane, is highly consumptive of protons (hydronium ions) which is why addition of sulfuric acid was required to maintain the $\mathrm{pH}$ of all bioreactors. The presence of calcite and other basic minerals (e.g. serpentine, chlorite) also contributed to the net acid consumption, which is a significant cost associated with reductive mineral bioprocessing (Johnson and du Plessis, 2015). It was interesting to note that the three limonite samples varied greatly in acid demand, with limonite sample L4 requiring $\sim 10-15$ times less acid to extract $\sim 1.5$ fold more cobalt than the other two samples. Sample L4 required 3 moles $\mathrm{H}_{2} \mathrm{SO}_{4} \mathrm{~g}^{-1}$ cobalt extracted, compared with 18 moles 
$\mathrm{g}^{-1}$ for $\mathrm{L} 1,67$ moles $^{-1}$ for L2, 48 moles $\mathrm{g}^{-1}$ for $\mathrm{L} 3$ and 28 moles $\mathrm{g}^{-1}$ for L5. Acid consumption was greater for the slag (L2) than all other samples tested, whereas the filter dust (L1) required less acid to maintain the bioreactor $\mathrm{pH}$ than the slag and two of the limonites. The amount of iron solubilised and acid consumed were highly correlated $\left(R^{2}>0.92\right)$ for all samples tested, apart from limonite $L 4$, providing strong supportive evidence that the reductive dissolution of iron (III) (hydroxy)oxides, as well as the destruction of carbonates and other acid-soluble minerals, was a major cause of acid consumption. Although the percentages of iron solubilised from all three limonites were relatively small compared to the percentage of the other transition metals leached, the large contents of iron (III) minerals in the ores meant that concentrations of iron (II) in PLS were always greater than those of manganese (II).

The strong correlation between cobalt and manganese in the limonite leachates $\left(R^{2}\right.$ $>0.90$ ) and in the bioleached mineral residues were in agreement with the finding that most of the cobalt present was associated with manganese (IV) minerals rather than with iron (III) minerals. Manganese oxyhydroxides can be solubilised either indirectly by microbiallygenerated ferrous iron or directly by some species of acidophilic bacteria (Ehrlich, 2008). While the objective in this study was to optimise cobalt extraction rather than nickel, the economics of the process would ultimately be dictated more by nickel than cobalt yields, since the former (currently the lower value metal) was present in orders of magnitude greater than the latter in all samples apart from the slag (L2).

The results from this study highlight the importance of mineralogical variability in dictating the amenabilities of different limonites to reductive bioprocessing. Combined mineralogical and elemental analysis showed that goethite was the most abundant iron (III) mineral in sample $L 3$, while $L 5$ was dominated by hematite and $L 4$ contained a mixture of the two minerals. Given the relative susceptibilities of the two iron (III) minerals to acid dissolution, it might have been anticipated that the concentration of soluble iron in L5 would have been less than in both L3 and L4 PLS, but this was not the case. In support of these data, a simple acid leaching test $(1 \mathrm{~g}$ of each of the limonite samples leached with $10 \mathrm{~mL}$ of $1 \mathrm{M}$ sulfuric acid, shaken at $30^{\circ} \mathrm{C}$ for 1 hour) generated concentrations of total soluble iron that followed a similar 
trend of that obtained in the bioreactors, with more iron being released from L5 $(\sim 350 \mathrm{mg} \mathrm{L-}$

346 1) than L3 ( $\left.200 \mathrm{mg} \mathrm{L}^{-1}\right)$, and both of these were orders of magnitude greater than L4 (4 mg

$347 \mathrm{~L}^{-1}$ ). EPMA analysis suggested that the hematite in $\mathrm{L} 5$ was partly hydrated and this altered-

348 type hematite may be the reason for high amounts of iron being solubilised in this sample.

349 Jang et al. (2007) demonstrated that hematite may get hydrated without structural

350 transformation to its fully hydrated equivalent (e.g. goethite) and also showed that such hydrated hematite presented higher solubility compared to non-hydrated hematite.

Another apparent anomaly was the relatively low amount and percentage of iron bioleached from sample L4, which contained appreciable amounts of goethite in addition to some hematite, and the largest percentage of total iron. XRD analysis showed that the peaks for hematite were broad, suggesting poorer crystallinity of this mineral phase, though this is not unusual in such materials. In addition, the peak height ratios between goethite and hematite were similar before and after bioleaching, suggesting that neither of these two minerals were dissolved or changed preferentially to the other. Analysis of the bioleached residue supported the low recovery rates for iron obtained from L4 leachates. It is interesting to note that, although the redox potential in L4 leachates by the end of the experiment were similar to those reached with samples L3 and L5, the decrease in $E_{h}$ values was far more protracted with L4. There were significant amounts of soluble iron (III) present in leachates for a large part of the experiment, and less manganese was also solubilised than from L3 and L5. This suggests a partial inhibition of the iron-reducing bacteria present, which would have in turn limited the rate of goethite dissolution by limiting the disequilibrium between soluble iron (III) and iron (II), which is thought to be the major driver in promoting the continued abiotic dissolution of iron (III) minerals in anaerobic conditions (Johnson and du Plessis, 2015). Concentrations of chromium and vanadium in L4 were greater than in samples L3 and L5. Both of these transition metals can occur as oxy-anions, which are, in general, far more toxic to bioleaching microorganisms than cationic transition metals, such as cobalt and nickel

371 (Dopson et al., 2014). Encouragingly, the relatively small amount of iron dissolved from L4 did 372 not seemingly impact yields of the chief target metal (cobalt), though less nickel was extracted 
373 from this limonite than the other two samples. The much lower acid consumption and amount

374 of iron solubilised would both have economic benefits to a full-scale process. Iron

375 (hydroxy)oxides in the Larco laterite samples contained relatively small amounts ( $0.9 \mathrm{wt} \%)$

376 of nickel, and, in these samples, this metal was, like cobalt, more concentrated in the

377 manganese oxide phases and in addition also in some silicates ( $>2 \mathrm{wt} \%$ in serpentine in 378 sample L3).

379 Concentrations of both cobalt and nickel in the slag (L2) were the lowest of the materials tested in this study, and large amounts of acid was consumed during reductive dissolution, generating PLS that contained $5.5 \mathrm{mg} \mathrm{L}^{-1}$ cobalt and $\sim 390 \mathrm{mg} \mathrm{L}^{-1}$ nickel. In contrast, PLS generated from the dust sample (L1), contained the largest concentrations of both of these metals of all five samples tested, though again had a large acid-demand (sevenfold more than limonite L4) and generated PLS with similar cobalt but much greater nickel could be due to different reasons, including: (i) some of the bacteria out competing others during the oxidative phase of sulfur oxidation, (ii) lack of $\mathrm{CO}_{2}$ provision during the bioleaching stage, (iii) the consortium not being adapted to the different materials prior to bioprocessing and (iv) the increase in concentration of potentially toxic metal oxyanions in the leachates.

\section{Conclusions}

This work has demonstrated the feasibility of bioleaching base metals from European limonitic laterite ores and waste materials from their processing under acidic, relatively low temperature, reducing conditions, using bacteria that couple the oxidation of zero-valent sulfur to the reduction of iron (III). High acid demand is one of the more significant OPEX associated with reductive mineral bioprocessing, and varied greatly between the five samples tested in 
401

402

403

404

405

406

407

408

409

410

411

412

413

414

415

416

417

418

419

420

421

422

423

424

425

426

427

428

429

430

431

432

433

434

435

436

437

438

439

440

441

442

the present study. The comprehensive mineralogical analysis of the three limonitic laterite samples revealed significant variations between the ores, and demonstrated that elemental and mineralogical variabilities can impact their amenability for bioleaching.

\section{Acknowledgments}

This work was supported by the European Union's EU Framework Programme for Research and Innovation Horizon 2020 ("CROCODILE”; grant number 776473). We are grateful for the support of LARCO staff, particularly Anthimos Xenidis and Yannis Kontos, and of Anastasios Kladis (Admiris).

\section{References}

Bridge, T.A.M. and Johnson, D.B., 2000. Reductive dissolution of ferric iron minerals by Acidiphilium SJH. Geomicrobiol. J. 17, 193-206.

https://doi.org/10.1080/01490450050121161.

Dalvi, A.D., Bacon, W.G., Osborne, R.C., 2004. The past and future of nickel laterites. PDAC 2004 International Convention, Trade Show \& Investors Exchange, 1-27.

Dopson, M., Ossandon, F.J., Lovgren, L., Holmes, D.S., 2014. Metal resistance or tolerance? Acidophiles confront high metal loads via both abiotic and biotic mechanisms. Front. Microbiol. 5, 157. https://doi.org/10.3389/fmicb.2014.00157.

Ehrlich, H.L., Newman, D.K., 2008. Geomicrobiology of manganese. In: Ehrlich, H.L., Newman, D.K. (eds.). Geomicrobiology. 5th edition. Boca Raton, FL: CRC Press. pp. 347420.

Hallberg, K.B., Grail, B.M., du Plessis, C.A., Johnson, D.B., 2011. Reductive dissolution of ferric iron minerals: a new approach for bio-processing nickel laterites. Miner. Eng. 24, 620624. https://doi.org/10.1016/j.mineng.2010.09.005.

Herrington, R., Mondillo, N., Boni, M., Thorne, R., Tavlan, M., 2016. Bauxite and NickelCobalt Lateritic Deposits of the Tethyan Belt. In: Richards et al. (eds.), Economic Geology Special Publication. 19, 249-387. https://doi.org/10.5382/SP.19.14.

Jang, J.H., Dempsey, B.A., Burgos, W.D., 2007. Solubility of Hematite Revisited: Effects of Hydration. Environ. Sci. Technol. 41:21, 7303-7308. https://doi.org/10.1021/es070535t.

Johnson, D.B., du Plessis, C., 2015. Biomining in reverse gear: using bacteria to extract metals from oxidized ores. Miner. Eng. 75, 2-5.

https://doi.org/10.1016/j.mineng.2014.09.024. 
Johnson, D.B., Grail, B.M., Hallberg, K.B., 2013. A new direction for biomining: extraction of metals by reductive dissolution of oxidised ores. Minerals 3, 49-58.

https://doi.org/10.3390/min3010049.

Johnson, D.B., Hedrich, S., Pakostova, E., 2017. Indirect redox transformations of iron, copper and chromium catalyzed by extremely acidophilic bacteria. Front. Microbiol. 8, 211. https://doi.org/10.3389/fmicb.2017.00211.

Lambiv Dzemua, G., Gleeson, S.A., Schofield, P.F., 2013. Mineralogical characterization of the Nkamouna Co-Mn laterite ore, southeast Cameroon. Miner. Deposita 48, 155-171. https://doi.org/10.1007/s00126-012-0426-3

Marrero, J., Coto, O., Goldman, S., Graupner, T., Schippers, A., 2015. Recovery of nickel and cobalt from laterite tailings by reductive dissolution under aerobic conditions using Acidithiobacillus species. Environ. Sci. Technol. 49, 6674-6682. https://doi.org/10.1021/acs.est.5b00944.

McDonald, R.G., Whittington, B.I., 2008. Atmospheric acid leaching of nickel laterites review. Part I. Sulphuric acid technologies. Hydrometallurgy 91, 35-55.

https://doi.org/10.1016/j.hydromet.2007.11.009.

Ñancucheo, I., Grail, B.M., Hilario, F., du Plessis, C., Johnson, D.B., 2014. Extraction of copper from an oxidised (lateritic) ore using bacterially catalysed reductive dissolution. Appl. Microbiol. Biotechnol. 98, 6297-6305. https://doi.org/10.1007/s00253-014-5687-6.

Ñancucheo, I., Rowe, O.F., Hedrich, S., Johnson, D.B., 2016. Solid and liquid media for isolating and cultivating acidophilic and acid-tolerant sulfate-reducing bacteria. FEMS Microbiol. Lett. 363. http://dx.doi.org/10.1093/femsle/fnw083.

Oxley, A., Smith M.E., Caceres, O., 2016. Why heap leach nickel laterites? Miner. Eng. 88, 53-60. http://dx.doi.org/10.1016/j.mineng.2015.09.018.

Roberts, S. and Gunn, A.G. (2014) Cobalt. In: Gunn, G. (ed.) Critical Metals Handbook, Oxford, Wiley-Blackwell. https://doi.org/10.1002/9781118755341.ch6.

Santos, A.L., Johnson, D.B., 2017. The effects of temperature and pH on the kinetics of an acidophilic sulfidogenic bioreactor and indigenous microbial communities. Hydrometallurgy 168, 116-120. https://doi.org/10.1016/j.hydromet.2016.07.018.

Smith, S.L., Grail, B.M., Johnson, D.B., 2017. Reductive bioprocessing of cobalt-bearing limonitic laterites. Miner. Eng. 106, 86-90. http://dx.doi.org/10.1016/j.mineng.2016.09.009.

Stookey, L.L., 1970. Ferrozine - a new spectrophotometric reagent for iron. Anal. Chem. 42, 779-781. https://doi.org/10.1021/ac60289a016.

US Geological Survey, 2020. Mineral commodities summaries. http://pubs.usgs.gov/periodicals/mcs2020/mcs2020.pdf. (accessed 2 March 2020). 

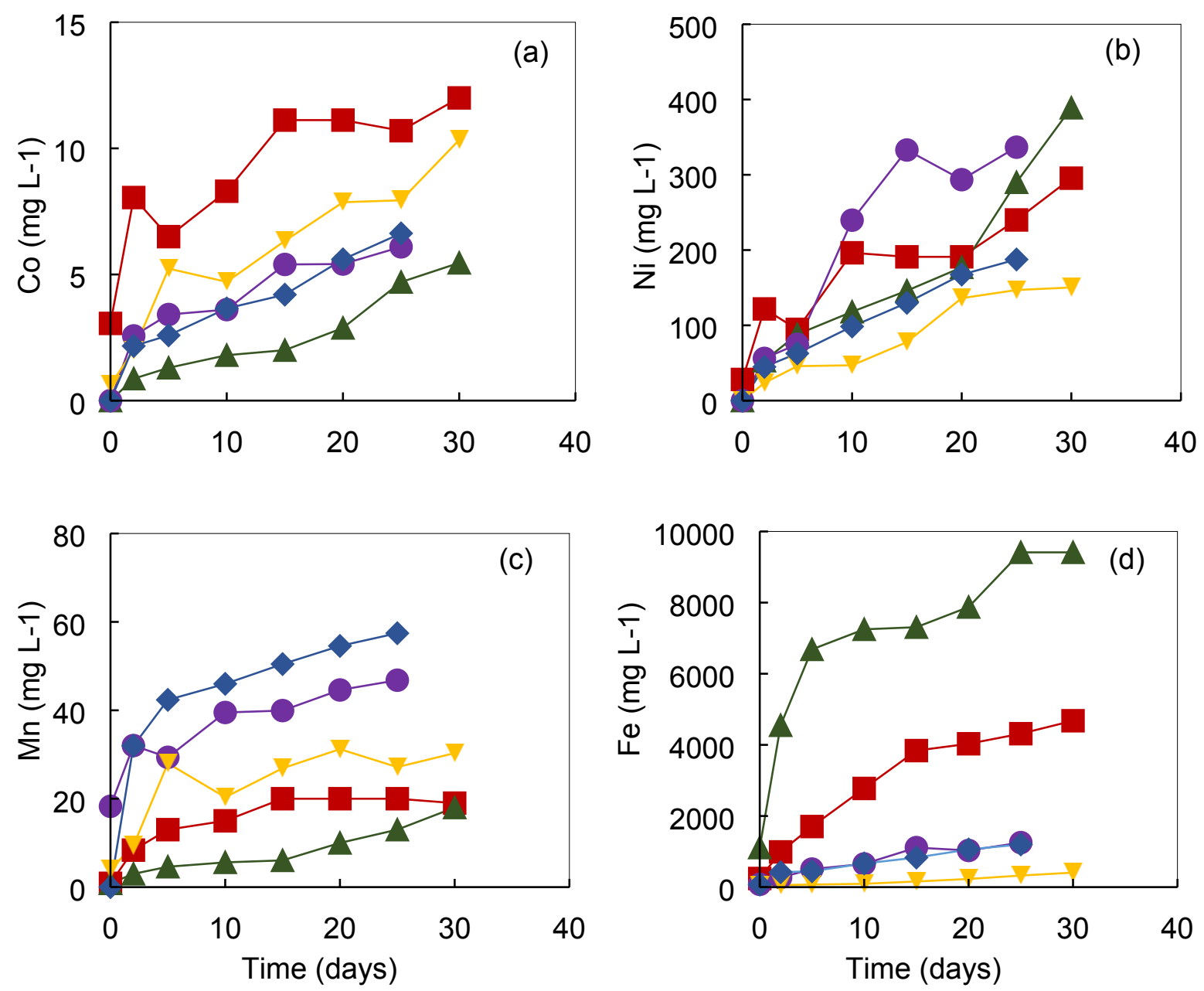

Figure 1. Changes in concentrations of soluble metals during bioprocessing of cobalt-bearing

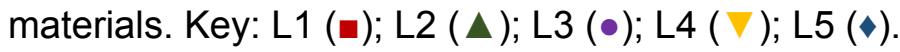



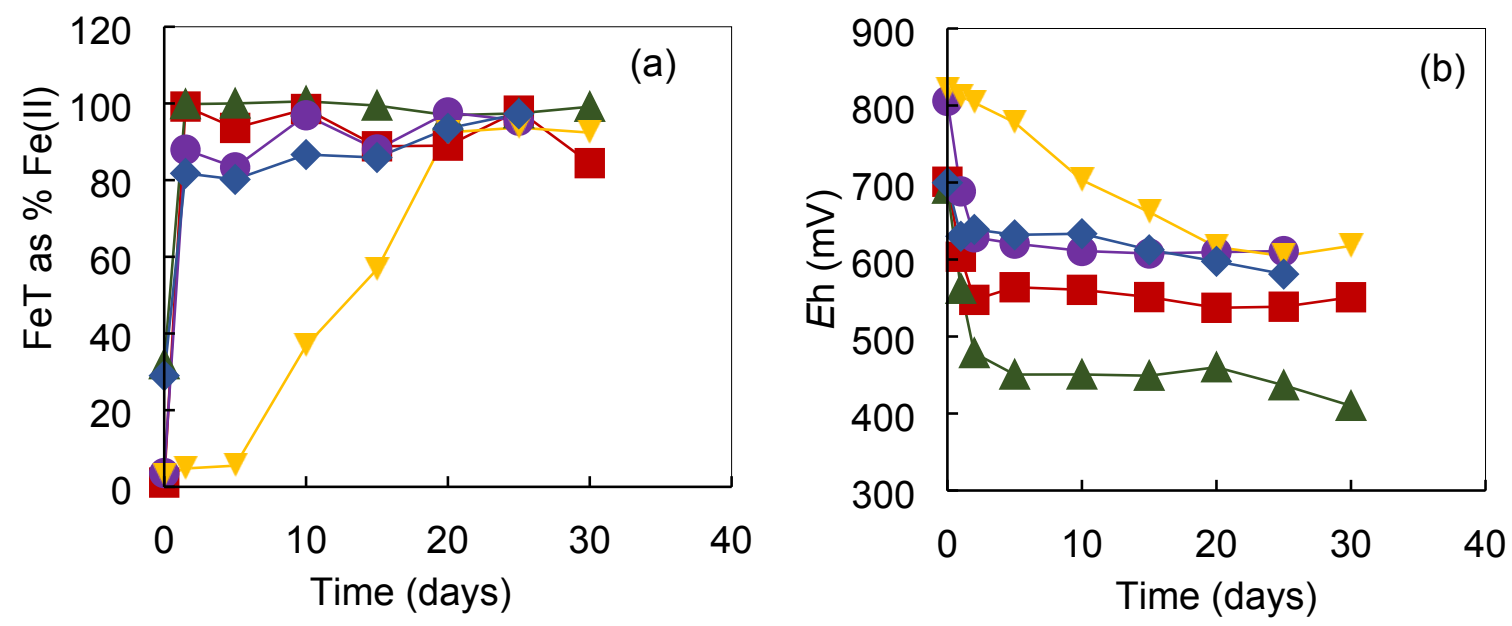

Figure 2. Changes in (a) concentrations of total soluble iron as a percentage of iron (II) and (b) redox potential values during reductive bioleaching of Co-bearing materials. Key: L1 ( $\square$ );

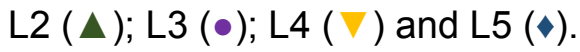




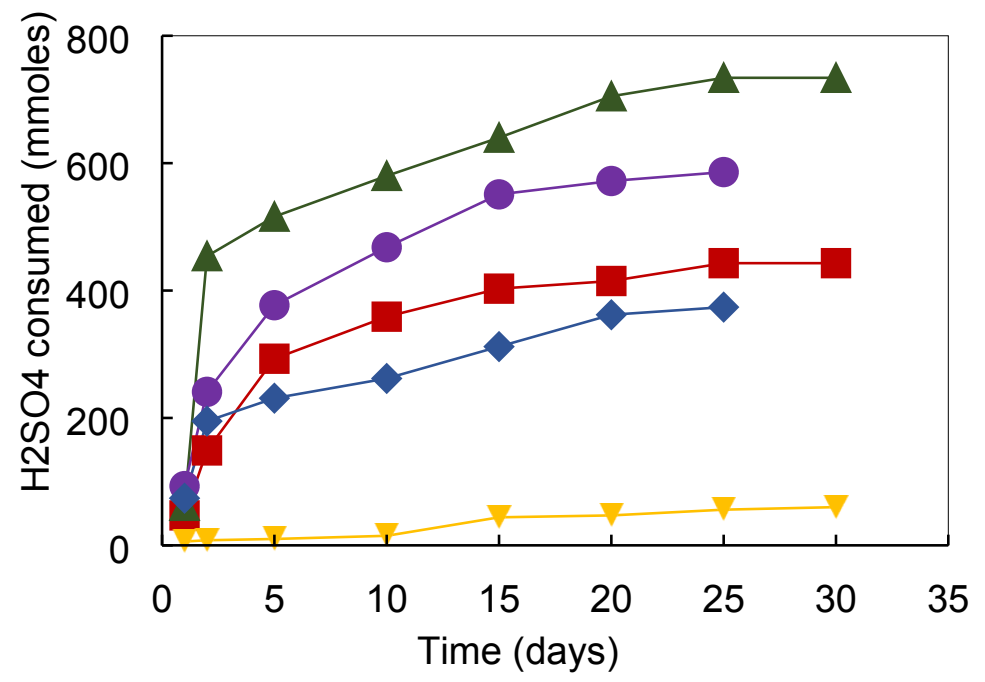

Figure 3. Cumulative amounts of sulfuric acid required to maintain bioreactors at $\mathrm{pH} 1.5$ during

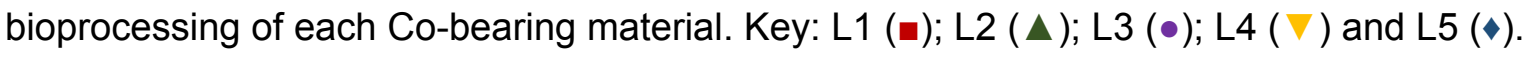



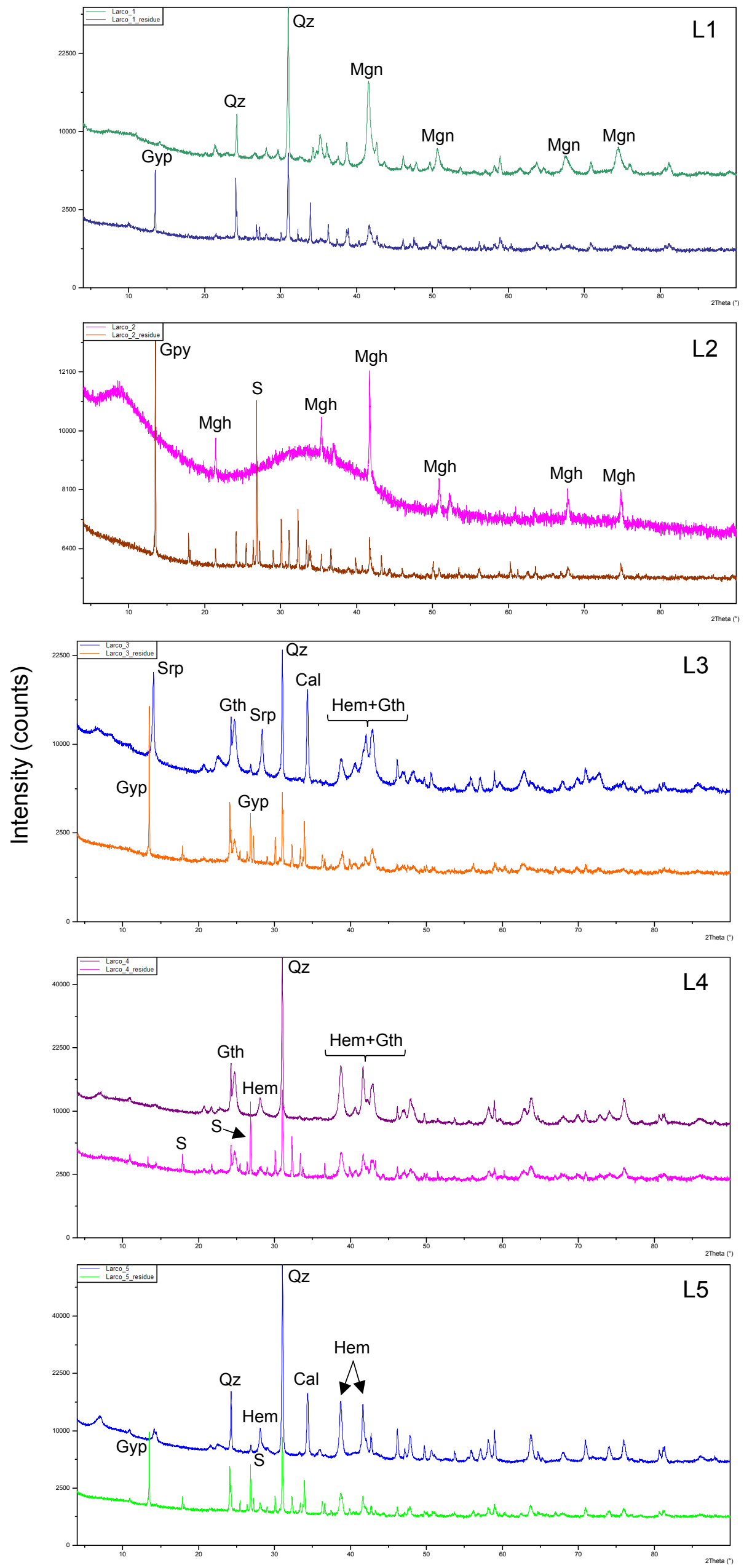
Figure 4. XRD patterns of the Larco samples before (upper pattern) and after (lower pattern) bioleaching. All leached residues had a lower intensity background indicating a reduction in total Fe concentration in the samples. Only the most prominent peaks on the patterns are labelled. Key: Qz-quartz; Mgn-magnetite; Gth-goethite; Mgh-maghemite; Hem-hematite; Calcalcite; Gyp-gypsum; S-ZVS, Srp-serpentine. 
Table 1. Summary of Co-bearing materials used in reductive bioleaching experiments.

\begin{tabular}{lll}
\hline Sample & Type of material & Location \\
\hline L1 & Filter dust & Larymna processing plant, Central Greece \\
L2 & Processed slag & Larymna processing plant, Central Greece \\
L3 & Limonite ore & Kastoria mine, Northern Greece \\
L4 & Limonite ore & Agios loannis mine, Central Greece \\
L5 & Limonite ore & Evia mine, Central Greece \\
\hline
\end{tabular}


Table 2. Mineral phases identified in bulk samples.

\begin{tabular}{cl}
\hline Sample & \multicolumn{1}{c}{ Mineral phases } \\
\hline L1 & Quartz, hematite, magnetite, olivine, enstatite, calcite, serpentine, smectite, illite \\
L2 & XRD-amorphous glassy material, maghemite, olivine \\
L3 & Quartz, goethite, hematite, calcite, serpentine, talc, smectite, sepiolite \\
L4 & Quartz, goethite, hematite, serpentine, chlorite, talc, smectite \\
L5 & Quartz, hematite, calcite, ankerite, serpentine, chlorite, talc, smectite \\
\hline
\end{tabular}


Table 3. Concentration of selected elements in the cobalt-bearing materials. Filter dust (L1), slag (L2), limonite ore from Kastoria mine (L3), limonite ore from Agios loannis mine (L4) and limonite ore from Evia mine (L5).

\begin{tabular}{lccccc}
\hline & $\mathrm{L} 1$ & $\mathrm{~L} 2$ & $\mathrm{~L} 3$ & $\mathrm{~L} 4$ & $\mathrm{~L} 5$ \\
\hline $\mathrm{Si}^{*}$ & 169 & 192 & 143 & 126 & 169 \\
$\mathrm{Al}^{*}$ & 38 & 34 & 5.2 & 29 & 21 \\
$\mathrm{Fe}^{*}$ & 182 & 281 & 160 & 346 & 215 \\
$\mathrm{Ca}^{*}$ & 36 & 32 & 42 & 2.3 & 57 \\
$\mathrm{Mg}^{*}$ & 57 & 46 & 105 & 21 & 42 \\
$\mathrm{Cr}^{*}$ & 14 & 21 & 6.8 & 18 & 10 \\
$\mathrm{Mn}^{*}$ & 2.6 & 2.6 & 2.3 & 2.2 & 2.2 \\
$\mathrm{Ni}^{*}$ & 11 & 1.1 & 10 & 8.2 & 5.6 \\
$\mathrm{Zn}^{* *}$ & 220 & 61 & 115 & 168 & 118 \\
$\mathrm{Cu}^{* *}$ & 44 & 18 & 17 & 38 & 23 \\
$\mathrm{~V}^{* *}$ & 152 & 209 & 66 & 197 & 122 \\
$\mathrm{Li}^{* *}$ & 40 & 30 & $<10$ & 10 & 40 \\
$\mathrm{~Pb}^{* *}$ & 22 & 3 & 4 & 5 & 9 \\
$\mathrm{Sc}^{* *}$ & 34 & 44 & 19 & 47 & 24 \\
$\mathrm{Ba}^{* *}$ & 151 & 67 & 14 & 23 & 93 \\
$\mathrm{Co}^{* *}$ & 602 & 97 & 334 & 516 & 274 \\
\hline $\mathrm{F}^{*}$ & & & & & \\
\hline
\end{tabular}

${ }^{*} \mathrm{kgg}^{-1 ; * *} \mathrm{mg} \mathrm{kg}^{-1}$ 
Table 4. Extraction of metals from limonite ores and processing residues (\%) based on the chemical composition of the PLS.

\begin{tabular}{lllll}
\hline Sample & Co & Ni & Mn & Fe \\
\hline L1 & 41 & 53 & 15 & 48 \\
L2 & 43 & 54 & 48 & 43 \\
L3 & 39 & 73 & 44 & 17 \\
L4 & 37 & 28 & 2 \\
L5 & 40 & 68 & 52 & 12 \\
\hline
\end{tabular}


Supplementary Table S1. Extraction of metals from limonite ores and processing residues (\%) based on the chemical composition of the bioleached residues.

\begin{tabular}{lllll}
\hline Sample & Co & $\mathrm{Ni}$ & $\mathrm{Mn}$ & $\mathrm{Fe}$ \\
\hline L1 & 49 & 57 & 62 & 52 \\
L2 & 25 & 10 & 48 & 43 \\
L3 & 52 & 63 & 57 & 22 \\
L4 & 38 & 39 & 4 \\
L5 & 47 & 68 & 79 & 27 \\
\hline
\end{tabular}



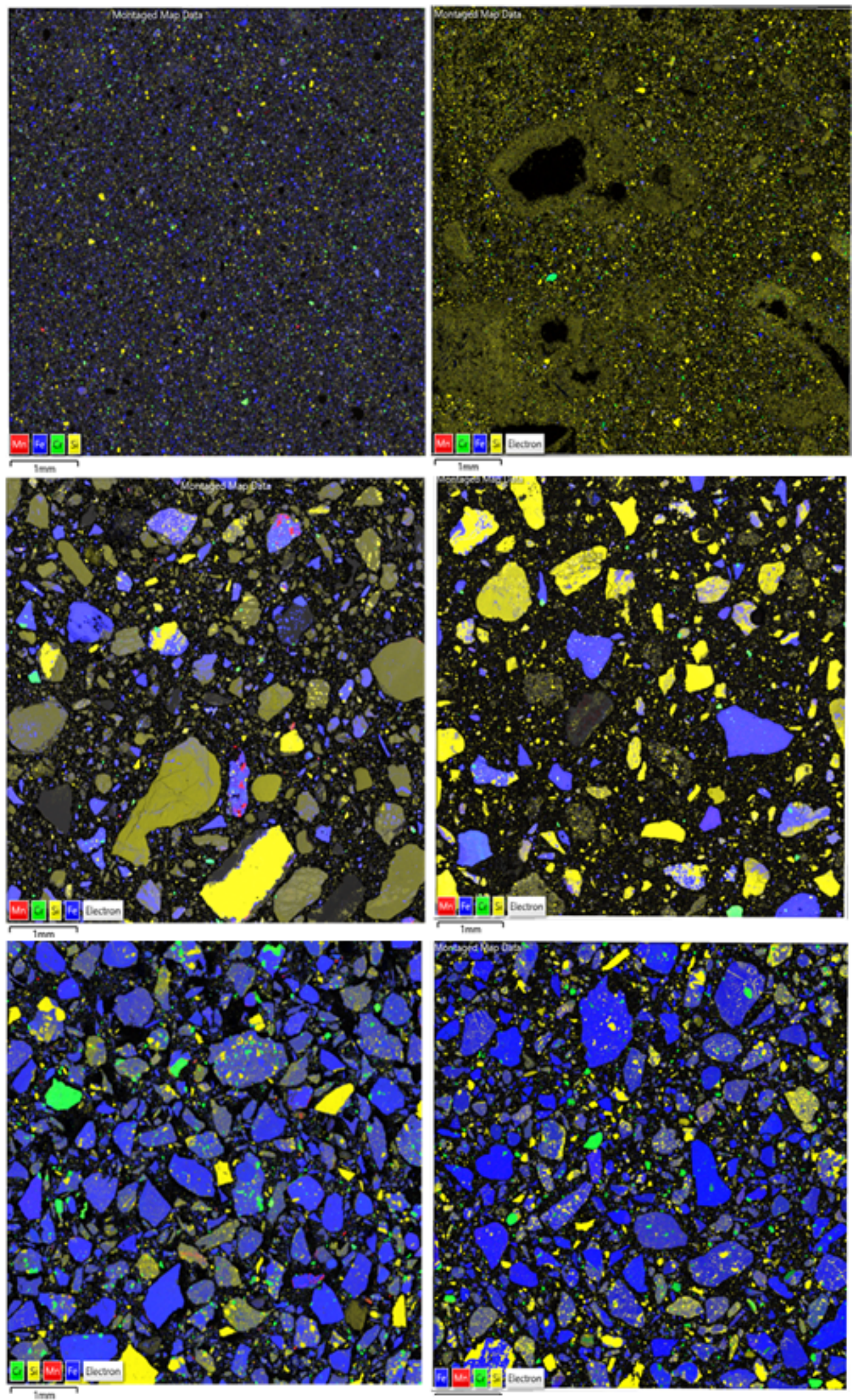

Supplementary Figure S1. SEM-EDX montaged maps showing distribution of manganese (red), iron (blue), chromium (green) and silicon (yellow) in Larco samples L1 (top), L3 (middle) and L4 (bottom) before (left panel) and after (right panel) bioleaching. Manganese oxyhydroxides (in L1 and L4) and manganese carbonate (in L3) were identified in the samples before leaching as confirmed by EDX spectra extracted from all manganese-rich areas indicated on the maps of the unleached samples. Manganese was not detected in the samples after leaching. 